\title{
Determination of available soil phosphorus by chemical methods
}

\author{
ERKKI AURA
}

Department of Agricultural Chemistry, University of Helsinki, 00710 Helsinki 71

\begin{abstract}
Phosphorus uptake by oats in pot experiments was compared with phosphorus test values obtained for experimental soils. Phosphorus was extracted from the soil using acid ammonium acetate solution, Bray 1 solution, Olsen solution, ammonium fluoride, distilled water and anion exchange resin. Intensity values were determined by equilibrating the soils with $0.01 \mathrm{M} \mathrm{CaCl}_{2}$ solution. Soil samples were collected from 30 mineral soils. The best test for phosphorus status proved to be the anion exchange resin method. Good results were also obtained with simple water extraction. An advantage of the water and resin method is that the microstructure of the soil is not substantially changed when using these methods. An intensity measurement was not in itself sufficient for analysis of the phosphorus status, since the intensity drops rapidly when soil releases phosphorus.
\end{abstract}

\section{Introduction}

The use of phosphorus as a fertilizer has increased greatly in Finland in recent years. Whereas the average use in 1965 was $21 \mathrm{~kg}$ per hectare, in 1975 it had increased to $35 \mathrm{~kg}$ per hectare. It has been estimated that our cultivated plants have used up $11 \mathrm{~kg}$ phosphorus/ha per year during this ten-year period (LATURI 1977). The positive balance of phosphorus is shown, for example, by the clearly increased content of phosphorus extracted from our soils by acid ammonium acetate during the 1960's (KURKI 1972). Apparently there are great differences between farms in their use of fertilizers. On the other hand, it is known that the capacity of Finnish soils to absorb phosphorus varies greatly (KAILA 1963). For this reason it is clear that in some fields an adequate supply of phosphorus can be ensured with a small amount of fertilizer, while in other fields a lot of phosphorus fertilizer must be added. The increased use of phosphorus fertilizers makes it necessary to determine whether simple chemical methods can give a reliable picture of the phosphorus condition of the soil.

An estimate of the phosphorus conditions of our soil was attempted as early as in the 1930's (TUORILA and TERÄSvUORI 1933, SAlonen 1939). A rather extensive study of the testing of our soils for phosphorus by chemical methods was made in the 1940's (KAILA 1949). Later, SALONEN (1957) and BRUMMER (1959) studied the possibility of assessing the need for phosphorus 
fertilizer by the soil testing method in general use in Finland which employs acid ammonium acetate as extracting solution.

According to KaILA's (1965) study, water soluble fertilizer phosphorus applied to Finnish soils is almost completely bound by oxides of aluminium and iron. Since Finnish soils by nature contain little available phosphorus, the phosphorus reserves available to plants in our fertilized soils are apparently bound to these oxides. In the present study an attempt was made to find a simple method of extracting the phosphorus bound to oxides of $\mathrm{Al}$ and $\mathrm{Fe}$ in order to get a reliable picture of the soil phosphorus condition.

\section{Materials and methods}

\section{a. Experimental soils}

Thirty mineral soil samples were collected form southern Finland, with the aim of getting a large variation in available phosphorus content. Thus one sample was taken from virgin soil, two from newly cleared land, and five from sugar beet fields which had received liberal amounts of phosphorus fertilizer. Particle size analyses were performed on the experimental soils using the method of ELONEN (1971), and the following distribution was obtained: Four of the samples were heavy clay, five were silty clay, ten were sandy clay and eleven were fine sand soils. The averages of $\mathrm{pH}$, organic carbon content and A1 and Fe extracted with TAmm's acid ammonium oxalate solution (1:20) are as follows:

\begin{tabular}{|c|c|}
\hline $\mathrm{pH} \ldots$. & $5.8 \pm 0.7$ \\
\hline Org. $\mathrm{C} \%$ of $\mathrm{DM}$ & $2.3 \pm 0.6$ \\
\hline Al mg/kg $\ldots \ldots \ldots \ldots \ldots \ldots \ldots$ & $3340 \pm 1150$ \\
\hline .............. & $5800 \pm 3330$ \\
\hline
\end{tabular}

The $\mathrm{pH}$ of the soils was measured in $0.01 \mathrm{M} \mathrm{CaC1}_{2}$ solution, the ratio of soil to solution being 1:2.5. The organic carbon content was estimated by wet combustion method (Graham 1948).

\section{b. Test methods}

1. Acid ammonium acetate method (VUORINEN and MăkıтIE 1955). The extractant was acid ammonium acetate, $0.5 \mathrm{M} \mathrm{CH}_{3} \mathrm{COONH}_{4}$ and $0.5 \mathrm{M} \mathrm{CH}_{3} \mathrm{COOH}$, with a pH of 4.65. Extraction was performed on $20 \mathrm{ml}$ of soil with $200 \mathrm{ml}$ acetate solution. The shaking time was one hour.

2. Bray 1 test. An extracting solution of $0.03 \mathrm{M} \mathrm{NH}_{4} \mathrm{~F}-0.025 \mathrm{M} \mathrm{HCl}$ was used (BrAY and KURTZ 1945). The volume ratio of soil to solution was $1: 20$, with a shaking time of one minute.

3. Bray 1 test as above but with an extraction time of 5 minutes.

4. Olsen test. Extraction was performed with a $0.5 \mathrm{M}$ solution of $\mathrm{NaHCO}_{3}\left(\mathrm{OLSEN}_{\mathrm{N}}\right.$ et al. 1954). The ratio of soil to extractant was $1: 20$ by volume. The shaking time was 20 minutes.

5. $\mathrm{NH}_{4} \mathrm{~F}$-test. An extracting solution of $0.5 \mathrm{M} \mathrm{NH}_{4} \mathrm{~F}$ with a $\mathrm{pH}$ of 8.5 was used. The ratio by volume of soil to solution was $1: 10$, and the shaking time was 15 minutes.

6. Water 1: 40 . On the day before extraction, $10 \mathrm{ml}$ of soil was moistened with $5 \mathrm{ml}$ of distilled water. The next day, $395 \mathrm{ml}$ of water was added to the shaking bottle, which was then shaken for 1 hour.

7. Water 1:400. One gram of the soil sample was weighed out and moistened with one $\mathrm{ml}$ of water. The next day, $399 \mathrm{ml}$ of water was added to the shaking bottle, which was then shaken for 2 hours. 


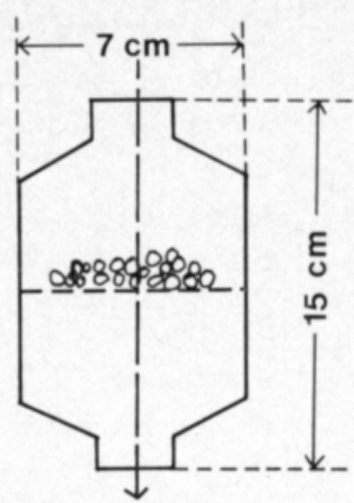

1. Leaching of soil out of the bottle

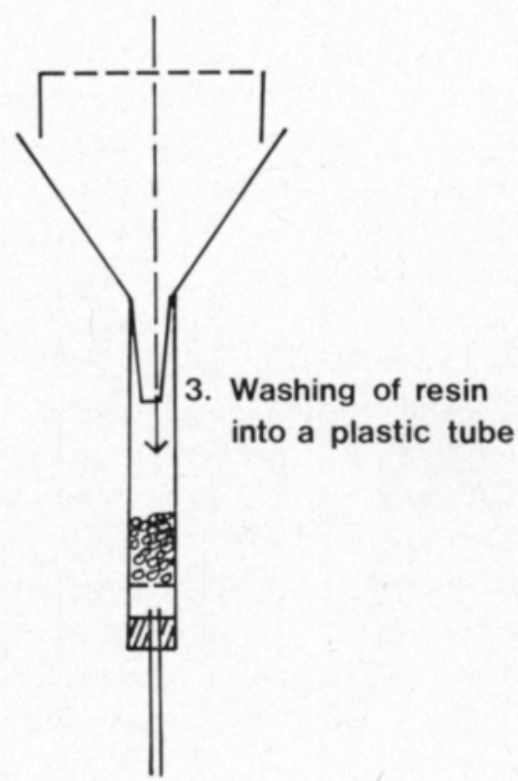

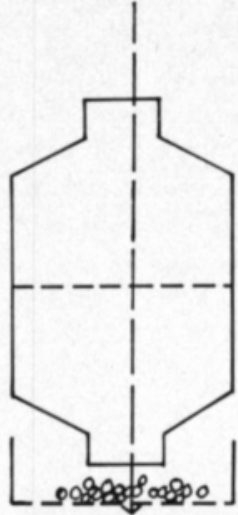

2. Transference of resin to a screen-bottomed cylinder

Fig. 1. Separation of anion exchange resin from soil and leaching of phosphate from resin.

8. Anion exchange resin method 5: 1 . The $\mathrm{Cl}$-form of Dowex $21-\mathrm{K}(16-20 \mathrm{mesh})$ exchange resin was used. Specially prepared plastic bottles with a volume of $400 \mathrm{ml}$ divided into two parts by a plastic screen were used for shaking (Fig. 1). Both ends of the bottle were provided with stoppers. On the day before extraction $10 \mathrm{ml}$ of the soil sample was moistened with $5 \mathrm{ml}$ of water. The next day 2 grams of anion exchange resin and $95 \mathrm{ml}$ of water were added on the other side of the screen. The bottles were mechanically shaken back and forth in a horizontal position for two hours. The the anion exchange resin was separated from the soil and the phosphorus was leached from the resin, as illusrated in Figure 1. A 0.25 M solution of $\mathrm{Na}_{2} \mathrm{SO}_{4}$ was used for leaching, $100 \mathrm{ml}$ of solution being used for each gram of resin. The time required to leach $200 \mathrm{ml}$ of solution was about one hour. The actual extraction is done by the water. The purpose of the anion exchange resin is to keep the phosphorus concentration of the water continuously at a low level. 
9. Anion exchange method $1: 1$. As in the above method, except that only $2 \mathrm{~g}$ of soil was used and this was moistened with $1 \mathrm{ml}$ of water.

10. $0.01 \mathrm{M} \mathrm{CaCl}_{2}$ method. $20 \mathrm{ml}$ of the soil sample was mixed with $50 \mathrm{ml}$ of $0.01 \mathrm{M} \mathrm{CaCl}_{2}$ $0.01 \% \mathrm{NaN}_{3}$ solution. The purpose of the sodium azide was to inhibit microbial activity. The suspension was allowed to stand for 24 hours, being stirred at intervals with a glass rod.

11. Method similar to that above in number 10. However, the suspension was allowed to stand for 2 weeks, since it was observed that equilibrium between soil and liquid is not always reached in 24 hours.

In grinding the soil samples prior to analysis, the attempt was made to avoid producing a fine powder. For methods $1,2,3,4,5,6,8,10$ and 11, in which the quantity of soil was $10 \mathrm{ml}$ or more, the soil was ground so that it barely passed through a sieve with holes $4 \mathrm{~mm}$ in diameter. For methods 7 and 9 the soil was ground enough to pass through a sieve with holes $2 \mathrm{~mm}$ in diameter. In the case of methods $1,2,3,4,5,10$ and 11, phosphorus was analyzed by the molybdenum blue method of KaILA (1955). In methods 6, 7, 8 and 9 a water analysis method used in Finland was employed (Juoma- ja talousvesien tutkimusmenetelmät 1969).

\section{c. Pot experiments}

Experimental plants were oats of the Hannes variety. Oats were chosen as the experimental plant, since the $\mathrm{pH}$ of the soil would not significantly affect the amount of yield. Pot experiments were done in a greenhouse. Using an automatic watering system, the surface of the soil in the pots during the growing time was kept at a water content approximating field capacity. The automatic watering system ensured that all plants received an equal amount of water, and 0.51 plastic pots sufficed for test pots. Each pot contained 0.41 of soil. The number of replications was four in the first growing. Two of these replications were saved for the second, third and fourth growings. During each growing the oats developed a thick root system in the experimental soil. Since roots were not removed, their presence apparently caused brisk microbial activity in the soil after harvesting. Because of the dense root system, most of the experimental soil probably came under the influence of the rhizosphere during the growings.

The oats shoots were harvested before ear emergence, and then dried and ground for plant analysis. Phosphorus determination of the shoots was made by dry ashing. Four consecutive growths took about one year. Fertilizer was applied during this time: $\mathrm{N} \mathrm{410,} \mathrm{K} \mathrm{560,} \mathrm{S} 110$ and $\mathrm{Mg} 90 \mathrm{mg} /$ pot. In addition, a commercial trace element mixture was added to each pot at the time of growing.

\section{Yields, uptake of phosphorus and test values}

The yields, phosphorus contents and uptake of phosphorus by plants based on 4 cuttings are shown in Table 1 . The third growing was in the autumn when natural light was weak, consequently the shoot yield from the third cutting was small compared to the others. The average uptake of phosphorus per liter of soil was $55 \mathrm{mg}$ in the yield from the first cutting, $22 \mathrm{mg}$ from the 
second cutting, $12 \mathrm{mg}$ from the third cutting and $16 \mathrm{mg}$ from the fourth cutting. Altogether, the shoots took up $105 \mathrm{mg} \mathrm{P}$ per liter of soil.

It can be calculated that if the yield of dry matter of plants grown in a field is, for example, $5000 \mathrm{~kg}$ and this contains $2 \mathrm{~g} \mathrm{P} / \mathrm{kg}$, the harvested plants have taken up $10 \mathrm{~kg}$ of phosphorus per hectare. If the depth of the top soil is $25 \mathrm{~cm}$, the shoots have taken up only $4 \mathrm{mg}$ of phosphorus per liter of soil. This example shows that in the pot experiments which were carried out, oats used a great deal of phosphorus from the test soils. Already in the first growth

Table 1. Yields of air dry matter, phosphorus contents and phosphorus uptake of shoots, Means and standard deviations of 30 soil samples.

\begin{tabular}{|c|c|c|c|c|}
\hline & 1 st yield & 2nd yield & 3rd yield & 4th yield \\
\hline Yield g/pot .................... & $6.8 \pm 0.6$ & $3.5 \pm 0.3$ & $0.8 \pm 0.2$ & $3.3 \pm 0.7$ \\
\hline P-content $\mathrm{mg} / \mathrm{g} \ldots \ldots \ldots \ldots . . .$. & $3.2 \pm 1.7$ & $2.6 \pm 1.1$ & $5.9 \pm 2.0$ & $1.9 \pm 0.5$ \\
\hline P-uptake $\mathrm{mg} /$ pot ............ & $22.2 \pm 12.0$ & $8.9 \pm 4.0$ & $4.7 \pm 1.5$ & $6.5 \pm 2.6$ \\
\hline
\end{tabular}

Table 2. Yields of air dry matter, phosphorus contents, and phosphorus uptake of shoots. Means and standard deviations of 15 soils containing slittles available phosphorus.

\begin{tabular}{lrrrr}
\hline & 1st yield & 2nd yield & 3rd yield & 4th yield \\
\hline Yield g/pot $\ldots \ldots \ldots \ldots \ldots \ldots \ldots$ & $6.7 \pm 0.7$ & $3.5 \pm 0.3$ & $1.0 \pm 0.3$ & $2.8 \pm 0.7$ \\
P-content $\mathrm{mg} / \mathrm{g} \ldots \ldots \ldots \ldots \ldots$. & $1.8 \pm 0.5$ & $1.7 \pm 0.4$ & $4.8 \pm 1.2$ & $1.6 \pm 0.3$ \\
P-uptake $\mathrm{mg} /$ pot $\ldots \ldots \ldots \ldots \ldots$ & $12.2 \pm 4.7$ & $6.0 \pm 1.6$ & $4.3 \pm 1.1$ & $4.5 \pm 1.4$ \\
\hline
\end{tabular}

of the pot experiment, the amount of phosphorus taken up corresponded to several years of phosphorus uptake in field conditions.

The average test values for the soil samples are presented in Table 3 . Because of the great variation in phosphorus status of the experimental soils, those 15 soils which took up the least amount of phosphorus in the first growing, were separated. The mean yields, phosphorus contents, and phosphorus uptake of shoots gorwn in the weakest soils are shown in Table 2. The test values of these soils appear in Table 4 .

Table 3. Test values of 30 soil samples.

\begin{tabular}{|c|c|c|c|c|}
\hline Test & $\begin{array}{c}\text { Lowest } \\
\text { value }\end{array}$ & $\begin{array}{c}\text { Highest } \\
\text { value }\end{array}$ & Mean & s \\
\hline $\mathrm{mg} \mathrm{P} / \mathrm{l}$ of soil & 1.0 & 119 & 40 & 36 \\
\hline 2. Bray $1,1 \mathrm{~min}$. & 15.0 & 825 & 194 & 185 \\
\hline 3. Bray 1,5 min. & 8.0 & 990 & 222 & 219 \\
\hline 4. Olsen & 17.5 & 167 & 71 & 37 \\
\hline 5. $\mathrm{NH}_{4} \mathrm{~F}$ & 0.0 & 645 & 89 & 124 \\
\hline 6. Water 1: 40 & 1.6 & 72 & 19 & 16 \\
\hline 7. Water 1: 400 & 6.7 & 99 & 30 & 25 \\
\hline 8. Resin 5: 1 & 1.5 & 88 & 30 & 23 \\
\hline 9. Resin 1: 1 & 2.0 & 114 & 40 & 31 \\
\hline 10. $\mathrm{CaCl}_{2}, 24$ hrs $\mathrm{mg} \mathrm{P} / 1$ of solution & 0.015 & 1.48 & 0.275 & 0.353 \\
\hline 11. $\mathrm{CaCl}_{2}, 2$ wks & 0.004 & 1.26 & 0.272 & 0.313 \\
\hline
\end{tabular}


Table 4. Test values of 15 soils containing sittles available phosphorus.

\begin{tabular}{|c|c|c|c|c|c|c|}
\hline \multicolumn{3}{|c|}{ Test } & \multirow{2}{*}{$\begin{array}{c}\begin{array}{c}\text { Lowest } \\
\text { value }\end{array} \\
1.0\end{array}$} & \multirow{2}{*}{$\begin{array}{c}\begin{array}{c}\text { Highest } \\
\text { value }\end{array} \\
36\end{array}$} & \multirow{2}{*}{$\begin{array}{r}\text { Mean } \\
12\end{array}$} & \multirow{2}{*}{$\begin{array}{l}\text { s } \\
9\end{array}$} \\
\hline & Acetate & $\mathrm{mg} \mathrm{P} / \mathrm{l}$ of soil & & & & \\
\hline & Bray $1,1 \mathrm{~min}$ & - & 15.0 & 132 & 80 & 42 \\
\hline & Bray $1,5 \mathrm{~min}$ & , & 8.0 & 179 & 92 & 52 \\
\hline & Olsen & , & 17.5 & 70 & 42 & 15 \\
\hline & $\mathrm{NH}_{4} \mathrm{~F}$ & , & 0.0 & 74 & 29 & 22 \\
\hline & Water 1: 40 & , & 1.6 & 17 & 7 & 4 \\
\hline & Water 1: 400 & , & 6.7 & 22 & 12 & 5 \\
\hline & Resin 5: 1 & , & 1.5 & 29 & 11 & 7 \\
\hline & Resin 1: 1 & , & 2.0 & 40 & 16 & 10 \\
\hline 10. & $\mathrm{CaCl}_{2}, 24 \mathrm{hrs}$ & $\mathrm{mg} \mathrm{P} / 1$ of solution & 0.015 & 0.19 & 0.060 & 0.052 \\
\hline 11. & $\mathrm{CaCl}_{2}, 2$ wks & , & 0.004 & 0.15 & 0.060 & 0.053 \\
\hline
\end{tabular}

\section{Test values as a measure of phosphorus status}

Tables 5 and 6 show the dependence of phosphorus uptake on test values. Dependence is expressed in coefficients of determination. Phosphorus uptake from the second cutting is not included, because the correlation for phosphorus uptake between the first and second growings is very high (0.911). The third growing is also omitted, since it was carried out in unusual lighting conditions.

Due to the great variation in phosphorus conditions, phosphorus uptake in the material of all samples was highly correlated with the different tests (Table 5). In experiments performed on soils containing little available phosphorus (Table 6) the relation between test values and phosphorus uptake was noticeably weaker. The best test for phosphorus status proved to be the anion exchange resin method $5: 1$. This result is a natural one, since in this method we, in effect, imitate the action of the root system by trying to take phosphorus from the soil, scarcely changing the microstructure of the soil. The method probably extracts labile phosphorus from the surface of pores of polymerous aluminium and iron oxides. Polymeric oxides apparently do not break up during extraction. For this reason, the phosphorus which is blocked inside the oxide is excluded from the analysis, since it diffuses extremely slowly to the surface of the oxide pores. The results given in Figure 2 confirm investigations made elsewhere suggesting that the anion exchange resin method is well suited for the analysis of available phosphorus (COOKE and Hislop 1963, COOKe 1966).

The water extraction also releases labile phosphorus from the surface of oxides. Indeed, the water 1: 40 method did correlate highly with the uptake of phosphorus. However, the correlation was low when using $1 \mathrm{~g}$ of soil and a 1: 400 ratio of soil to water. Partly this is due to filtration difficulties with the 1: 400 extraction ratio. However, also when using the anion exchange resin method with $2 \mathrm{~g}$ of soil (1: 1 method), the results showed lower correlation with phosphorus uptake than when $10 \mathrm{ml}$ of soil was used. The reason for the poor results cannot be an excessively powerful extraction of phosphorus with the water 1: 400 method, since the use of the ratio 1: 400 released the same 


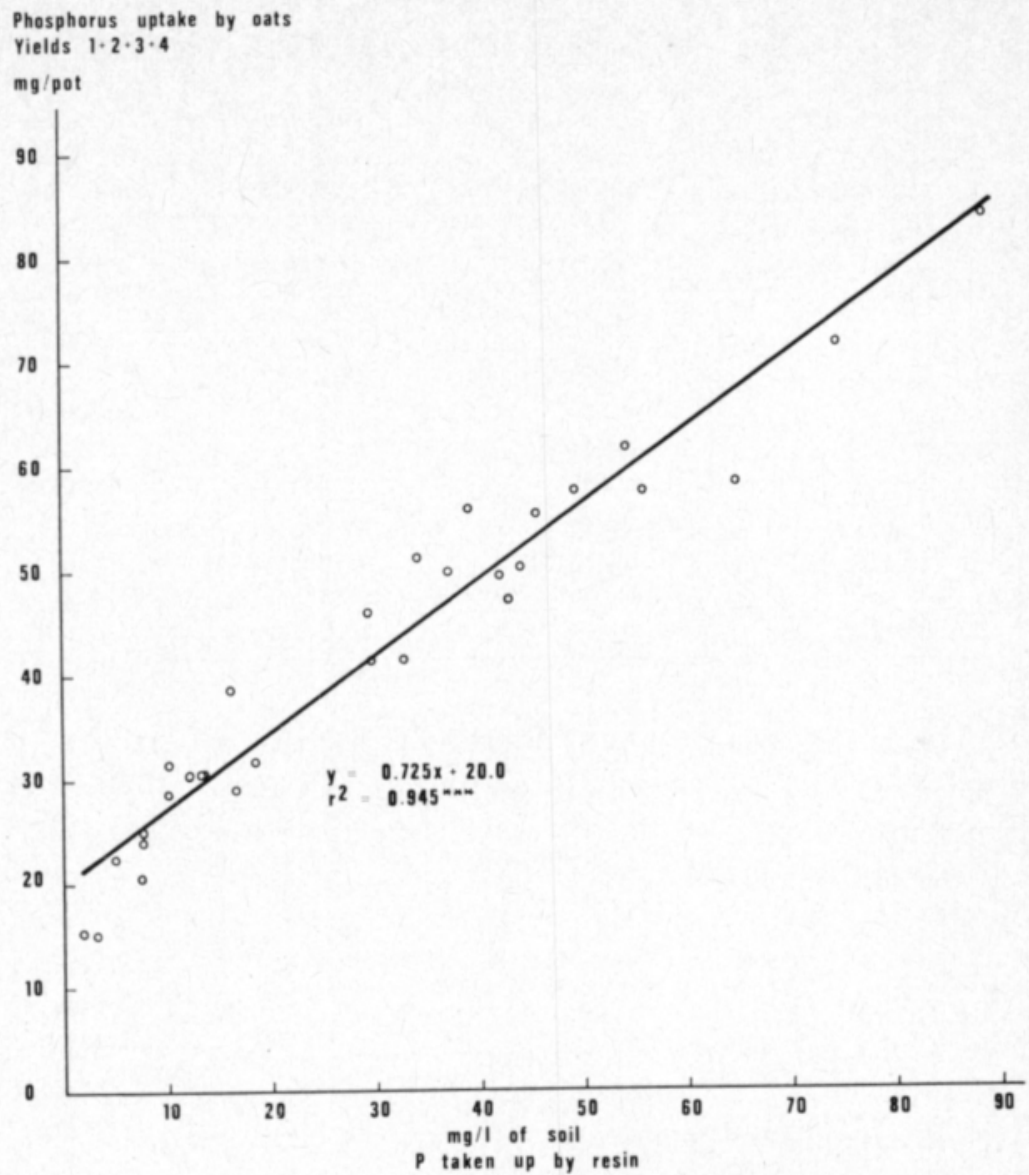

Fig. 2. Comparisons of phosphorus uptake by oats and phosphorus uptake from the same soils by an anion-exchange resin (5:1).

Table 5. Dependence of phosphorus uptake on test values of soils, expressed in coefficients of determination. All 30 test soils.

\begin{tabular}{|c|c|c|c|}
\hline \multirow{2}{*}{ Test } & \multicolumn{3}{|c|}{$\mathrm{r}^{2}$} \\
\hline & 1st yield & 4th yield & Yields $1+2+3+4$ \\
\hline 1. Acetate ......................... & $0.754^{* * *}$ & $0.795^{* * *}$ & $0.768^{* * *}$ \\
\hline 2. Bray 1, 1 min. $\ldots \ldots \ldots \ldots \ldots \ldots$ & $0.704 * * *$ & $0.453^{* * *}$ & $0.484 * * *$ \\
\hline 3. Bray 1, 5 min. $\ldots \ldots \ldots \ldots \ldots \ldots$ & $0.663^{* * *}$ & $0.445^{* * *}$ & $0.438^{* * *}$ \\
\hline 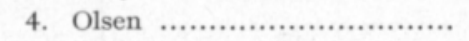 & $0.696 * * *$ & $0.767^{* * *}$ & $0.688^{* * *}$ \\
\hline 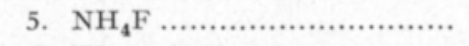 & $0.506 * * *$ & $0.298^{* *}$ & $0.287 * *$ \\
\hline 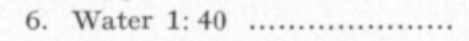 & $0.871^{* * *}$ & $0.770^{* * *}$ & $0.862^{* * *}$ \\
\hline 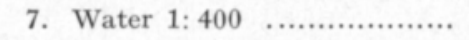 & $0.529 * * *$ & $0.647^{* * *}$ & $0.602^{* * *}$ \\
\hline 8. Resin $5: 1, \ldots \ldots \ldots \ldots \ldots \ldots \ldots \ldots \ldots \ldots \ldots \ldots$ & $0.908 * * *$ & $0.820^{* * *}$ & $0.945^{* * *}$ \\
\hline 9. Resin 1: $1, \ldots \ldots \ldots \ldots \ldots \ldots \ldots \ldots \ldots \ldots \ldots$ & $0.692^{* * *}$ & $0.771^{* * *}$ & $0.809 * * *$ \\
\hline 10. $\log \mathrm{CaCl}_{2}, 24 \mathrm{hrs} . \ldots \ldots \ldots \ldots$ & $0.805^{* * *}$ & $0.647^{* * *}$ & $0.807^{* * *}$ \\
\hline 11. $\log \mathrm{CaCl}_{2}, 2$ wks $\ldots \ldots \ldots \ldots . .$. & $0.708^{* * *}$ & $0.614 * * *$ & $0.751^{* * *}$ \\
\hline
\end{tabular}

* significant at the level of $\mathrm{P}=5 \%$

$\begin{array}{lll}* * & \mathrm{P}=1 \% \\ * * * & \mathrm{P}=0.1 \%\end{array}$


Table 6. Dependence of phosphorus uptake on test values of soils expressed in coefficients of determination. 15 soils containing slittle available phosphorus.

\begin{tabular}{|c|c|c|c|c|}
\hline \multirow{2}{*}{\multicolumn{2}{|c|}{ Test }} & \multicolumn{3}{|c|}{$\mathrm{r}^{2}$} \\
\hline & & 1st yield & 4 th yield & Yields $1+2+3+4$ \\
\hline 1. & Acetate...$\ldots \ldots \ldots \ldots \ldots \ldots \ldots \ldots \ldots \ldots \ldots \ldots$ & $0.325^{*}$ & $0.629 * * *$ & $0.395^{*}$ \\
\hline 2. & Bray 1,1 min. $. . . \ldots \ldots \ldots \ldots . . . .$. & $0.520^{* *}$ & $0.793 * * *$ & $0.593 * * *$ \\
\hline 3. & Bray 1, 5 min. ................ & $0.331^{*}$ & $0.651 * * *$ & $0.421^{* *}$ \\
\hline 4. & 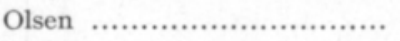 & 0.249 & $0.618^{* * *}$ & $0.308^{*}$ \\
\hline 5. & 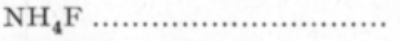 & 0.222 & $0.530 * *$ & $0.293^{*}$ \\
\hline 6. & 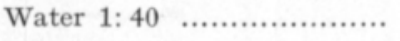 & $0.704 * * *$ & $0.531 * *$ & $0.695 * * *$ \\
\hline 7. & Water 1: $400 \quad \ldots . . . \ldots . . . \cdots . . . .$. & $0.492 * *$ & $0.267 *$ & $0.433 * *$ \\
\hline 8. & Resin $5: 1, \ldots \ldots \ldots \ldots \ldots \ldots \ldots \ldots \ldots \ldots \ldots$ & $0.744 * * *$ & $0.605^{* * *}$ & $0.789 * * *$ \\
\hline 9. & 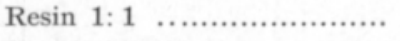 & $0.745^{* * *}$ & $0.486 * *$ & $0.754 * * *$ \\
\hline 10. & Log $\mathrm{CaCl}_{2}, 24$ hrs $\ldots \ldots \ldots \ldots \ldots$ & $0.406^{*}$ & 0.257 & $0.436 * *$ \\
\hline 11. & Log $\mathrm{CaCl}_{2}, 2$ wks $\ldots \ldots \ldots \ldots \ldots$ & 0.255 & 0.177 & $0.328^{*}$ \\
\hline
\end{tabular}

amount of phosphorus from the soil as did the anion exchange resin $5: 1$ method (Tables 3 and 4). The grinding of the soil may have partly affected the test results. When $1 \mathrm{~g}$ of soil was used for analysis the soil was ground finer than when $10 \mathrm{ml}$ of soil was used (see methods).

The results of water extraction 1: 40 are in agreement with results obtained elsewhere. VAN DER PAAUW (1971) demostrated in experiments with wheat and potatoes that water extraction gives a reliable indication of the soil phosphorus status. Köster (1974) observed in experiments with potatoes that water extraction is more reliable than many other methods in measuring the available phosphorus of soil.

The acid ammonium acetate method and the anion exchange resin method were almost equally effective in extraction. However, the correlation between the phosphorus uptake and the test in the first growing and in all 4 growings combined is noticeably lower with acid ammonium acetate than with the anion exchange resin method in the group of weak phosphorus status (Table 6). Apparently, acid ammonium acetate breaks up the structure of aluminium oxide polymers more effectively than resin. Indeed, acid ammonium acetate is used for the extraction of aluminium hydroxides from soil (MCLEAN et al. 1964). When aluminium oxide polymers break up, the ammonium acetate probably also extracts some phosphorus which is not labile. This was apparently the case when the soil $\mathrm{pH}$ was high $(>6.0)$. The analysis results reveal that acid ammonium acetate extracted phosphorus effectively when the soil pH was close to neutral (compare KURKI 1972, p. 59). The actual uptake of phosphorus by oats did not improve as much with an increase in $\mathrm{pH}$ as the acetate test results would lead one to expect. It was possible to prove this by a regression analysis using as independent variables, in addition to the test value, soil $\mathrm{pH}$ and test value $\mathrm{xpH}$. The dependent variable was the uptake of phosphorus in the first growing. The following regression equation was obtained:

All 30 experimental soils:

$$
\begin{gathered}
\text { Uptake }=1.19 * * * \times \text { test }+2.07 \times \mathrm{pH}-0.145^{* * *} \mathrm{x}(\text { test } \mathrm{x} \mathrm{pH})-1.83 \\
\mathrm{R}^{2}=0.875
\end{gathered}
$$


The variable, test $\mathrm{xpH}$ had a statistically significant negative effect on the uptake of phosphorus. This shows that when the soil $\mathrm{pH}$ was high, the test gave too positive a picture of the soil phosphorus status.

Apparently, $\mathrm{NaHCO}_{3}$ and extraction solutions containing fluorides break up the structure of oxides of $\mathrm{Al}$ and $\mathrm{Fe}$ more effectively than does an acid ammonium acetate solution. When polymeric oxides break up, phosphorus which is not available to plants probably enters into the analysis. These methods are not as good as the water method and resin method for explaining the uptake of phosphorus in the first growing and the combined uptake of all four growings, especially with soils containing little available phosphorus. For these, the best of the tests proved to be the one minute extraction using Bray 1 solution. In the soil group containing little available phosphorus, this method explained $52 \%$ of the uptake of phosphorus in the first growing and $59 \%$ of the combined uptake of all four growings. Perhaps the one minute extraction with Bray solution changed the soil microstructure less than when longer extraction times and strong extraction solutions were used.

The weak correlation of the ammonium fluoride method with the phosphorus uptake can be explained by the fact that fluoride extracts too little iron oxide bound phosphate. The Olsen test did not prove especially reliable for predicting the phosphorus uptake of oats. With 15 soils containing little available phosphorus, the method explained only $25 \%$ of the phosphorus uptake in the first growing, and only $31 \%$ of the combined uptake of all 4 growings.

Intensity measurements gave a weak prediction of the phosphorus uptake in the group of $\mathbf{1 5}$ soils. This result is not surprising, since already in the first growing the shoots took up, on the average, $31 \mathrm{mg}$ phosphorus/liter from these soils. Intensity measurements pictured conditions in the soil only before planting. During the time of phosphate desorption the intensity falls rapidly (VAIDYAnathan and NyE 1970). Although the phosphorus uptake per liter of soil is much smaller in field conditions than in pot experiments, the applicability of intensity measurement to field conditions is questionable. The root system does not take phosphorus uniformly from all of the top soil, but takes it especially from soil near the root surface (BHAT and NyE 1973). Better results could probably be obtained by constructing a curve to show the relationship between phosphorus intensity and labile phosphorus. This method, however, would involve much laboratory work. The usefulness of such a curve is reduced by the fact that the shape of the desorption curve is ambiguous, differing from the curve for phosphate adsorption. The shape of the curve depends greatly, among other things, on how much phosphate has been applied to the soil before desorption (Vaidyanathan and NyE 1970).

\section{Test methods and capacity factor of phosphorus conditions}

The phosphorus uptake from soils containing little available phosphorus was predicted, in regard to the 4 th cutting, more successfully by the Bray, the acid ammonium acetate and the Olsen tests than by the water extraction or the anion exchange resin method. This may be because the plants have 
already used the most labile part of the soil phosphorus before the fourth planting. In the fourth growing, the plants have been dependent on the less labile phosphate reserves, which were probably not extractable by water or by anion exchange resin. However, the water method and the anion exchange resin method also measure the capacity factor of the soil phosphorus status. We have alredy seen that the uptake of phosphorus in the first growing, in which oats already took up a great deal of phosphorus from the soil and in all 4 grovings, was highly correlated with the phosphorus extracted by the water method and by the resin method.

According to studies made by Cooke (1966), the amount of phosphorus extracted from the soil by resin depends on extraction time in the following manner: $Q=a \sqrt{t}+b$ where $Q$ is the amount of phosphorus desorbed from the soil, $\mathrm{t}$ is the extraction time, and $\mathrm{a}$ and $\mathrm{b}$ are both constants. Unpublished experiments made by the present author showed, with regard to Finnish soils, that the value of constant $\mathrm{b}$ is small, being at most only a few $\mathrm{mg} \mathrm{P} / \mathrm{kg}$ of soil. Constant a indicates not only how easily phosphate desorbs from the soil, but also how much phosphorus can be released from the soil when extraction time with resin is long. Even with only one extraction we can get an approximate idea of the value of a and at the same time an idea of the capacity factor of the phosphorus status.

The water method also gives an idea of the capacity factor. The reason is probably that soils which contain great amounts of very labile, water soluble phosphorus also usually contain a lot of less labile but available phosphorus reserves. This is shown by the correlation coefficients between the water method 1: 40 and the anion exchange resin methods 5: 1 and 1: 1 , which were 0.959 and 0.831 respectively. In another study made by the author, which involved 80 mineral soil samples, the correlation coefficient between the water method $(1: 40)$ and the resin method (5: 1) was 0.900.

\section{Conclusions}

On the basis of experimental results, the best methods for measuring the soil phosphorus status are the water method 1: 40 and the anion exchange resin methods. Naturally we cannot, merely by measuring the phosphorus status predict, in practice, the effect of applied phosphorus fertilizer. The increase in yield attained with phosphate depends not only on the phosphorus status but also, among other things, on how much the phosphorus status changes due to fertilization. Also, numerous other factors such as, for example, the growth of the root system and weather conditions have an effect on the uptake of soil phosphorus.

Acknowledgement. The author wishes to thank Kemira Oy:n Tutkimussäätiö for financial aid for this study. 


\section{REFERENCES}

Anon. 1969. Juoma- ja talousvesien tutkimusmenetelmät. 169 p. Helsinki.

Bhat, K. K. S. \& NyE, P. H. 1973. Diffusion of phosphate to plant roots in soil. I Quantitative autoradiography of the depletion zone. Plant and Soil 38: 161-175.

Bray, R. H. \& Kurtz, L. T. 1945. Determination of total, organic and available forms of phosphorus in soils. Soil Sci. 59: 39-45.

Brummer, V. 1959. Lannoituksen vaikutuksesta sokerijuurikkaan satoon. Acta Agr. Fenn. 94: 201-239.

Cooke, I. J. 1966. A kinetic approach to the description of soil phosphate status. J. Soil Sci. 17: $56-64$.

_ \& Hislop J. 1963. Use of anion-exchange resin for the assessment of available soil phosphate. Soil Sci. 96: 308-312.

Elonen, P. 1971. Particle-size analysis of soil. Acta Agr. Fenn. 122: 1-122.

Graham, E. R. 1948. Determination of soil organic matter by means of a photoelectric colorimeter. Soil Sci. $65: 181-183$.

KAILA, A. 1949. Maan fosforintarpeen määrittämisestä. Valt. Maatal.koetoim. Tiedonantoja 220: $1-24$.

- 1955. Studies on the colorimetric determination of phosphorus in soil extracts. Acta Agr. Fenn. 83: 25-47.

- 1963. Dependence of the phosphate sorption capacity on the aluminium and iron in Finnish soils. J. Scient. Agric. Soc. Finl. 35: 165-177.

- 1965. The fate of water-soluble phosphate applied to some mineral soils. J. Scient. Agric. Soc. Finl. 37: 104-115.

KURKI, M. 1972. Suomen peltojen viljavuudesta II. 182 p. Helsinki.

Köster, W. 1974. Beziehung zwischen dem Phosphorgehalt won Kartoffelkraut und Böden. Z. Pflanzenern. Düng. Bodenk. 137: 19-30.

LAturi, R. 1977. Typpi-, fosfori- jn kaliumlannoituksen kehitys Suomessa. Kehittyvä Maatalous 36: 3-10.

Mclean, E. O., Hourigan, W. R., Shoemaker, H. E. \& Bhumbla, D. R. 1964. Aluminum in soils: V Form of aluminum as a cause of soil acidity and a complication in its measurement. Soil Sci. 97: 119-126.

Olsen, S. R., Cole, C. V., Watanabe, F. S. \& Dean L. A. 1954. Estimation of available phosphorus in soils by extraction with sodium bicarbonate. U. S. Dept. Agr. Circ. 939. $19 \mathrm{p}$.

SALONEN, M. 1939. Amerikkalaisten pikamenetelmien käytöstä maan fosfaatti- jn kalilannoitustarpeen määräämiseksi. J. Scient. Agric. Soc. Finl. 11: 271-290.

- 1957. Fosfaattilannoitusta koskevia tutkimuksia. Valt. Maatal. koetoim. Julk. 164: $1-104$.

TUORILA, P. \& TERĀsvuori A. 1933. Untersuchungen über die Anwendbarkeit der bodenanalytischen Methoden für die Bestimmung des Düngebedürfnisses. Valt. Maatal. koetoim. Julk. 56: 1-67.

VAIDYANATHAN, L. V. \& NYE, P. H. 1970. The measurement and mechanism of ion diffusion in soils. VI the effect of concentration and moisture content on the counterdiffusion of soil phosphate against chloride ion. J. Soil Sci. 21: 15-27.

VAn Der PaAuw, F. 1971. An effective water extraction method for the determination of plant-available soil phosphorus. Plant and Soil 34: 467-481.

Vuorinen, J. \& Mäкitie, O. 1955. The method of soil testing in use in Finland. Agrogeolog. Publ. 63: 1-44.

Ms received June 28, 1978. 


\section{Käyttökelpoisen fosforin määrittäminen maasta kemiallisin menetelmin}

\section{ERkKi AUrA}

Yliopiston maanviljelyskemian laitos, 00710 Helsinki 71

Kauralla tehtyjen astiakokeiden avulla verrattiin kasvin fosforin ottoa koemaista analysoituihin fosforin testiarvoihin. Fosfori uutettiin maasta happamella ammoniumasetaattiliuoksella ( $\mathrm{pH}$ 4.65), Bray 1-liuoksella, Olsenin liuoksella, ammoniumfluoridilla, tislatulla vedellä ja anioninvaihtajalla. Lisäksi määritettiin koemaille intensiteetti tasapainottaen maita $0.01 \mathrm{M} \mathrm{CaCl}_{2}$-liuoksen kanssa. Koemaina oli 30 mineraalimaata, joiden fosforitilanne vaihteli suuresti. Samoja maita käytettiin neljään peräkkäiseen kasvatukseen. Tuloksia käsiteltäessä erotettiin aineistosta 15 sheikkokuntoisen maan ryhmä, joiden kohdalla kauran fosforin saanti oli 1. kasvatuksessa vähäisintä.

Parhaiten ennusti fosforin ottoa anioninvaihtajamenetelmä, jossa $10 \mathrm{ml}$ maata uutettiin 2 g:lla anioninvaihtajaa kahden tunnin ajan. Menetelmä selitti koko aineistossa $91 \%$ ensimmäisen sadon fosforin oton vaihtelusta ja $95 \%$ neljän sadon sisältämän fosforin vaihtelusta. Heikkokuntoisten maiden ryhmässä vastaavat selitysasteet olivat 74 ja $79 \%$. Hyviin tuloksiin päästiin myös yksinkertaisella tunnin vesiuutolla, jossa maan määrä oli $10 \mathrm{ml}$ ja veden tilavuus $400 \mathrm{ml}$. Tämä menetelmä selitti koko aineistossa $87 \%$ ensimmäisen kasvatuksen fosforin otosta ja $86 \%$ neljän peräkkäisen sadon fosforin otosta. Vähän käyttökelpoista fosforia sisältävien maiden ryhmässä selitysasteet olivat 70 ja $69 \%$.

Vesi- ja anioninvaihtajamenetelmien etuna katsottiin olevan, että niitä käytettäessä maan mikrorakenne muuttuu vain vähän. Sen sijaan varsinaiset uuttoliuokset hajoittavat huokoisia Al- ja Fe-oksidipolymeereja, jolloin analyysiin saadaan mukaan fosforia, joka ei ole kasveille käyttökelpoista. Tutkimuksessa kiinnitettiin myös huomiota siihen, että sekä anioninvaihtajaettä vesimenetelmä eivät mittaa ainoastaan, kuinka helposti maasta desorboituu fosforia, vaan antavat myös käsityksen fosforitilanteen kapasiteettitekijästä. Pelkkä intensiteetin mittaus $0.01 \mathrm{M} \mathrm{CaCl}_{2}$-liuoksella ei riitä fosforitilanteen analysoimiseen, koska intensiteetti alenee nopeasti, kun maasta desorboituu fosfaattia. 